\title{
Hsp27 regulates podocyte cytoskeletal changes in an in vitro model of podocyte process retraction
}

\author{
WILLIAM E. SMOYER AND RICHARD F. RANSOM ${ }^{1}$ \\ Pediatric Nephrology Division, University of Michigan, Ann Arbor, Michigan 48109, USA
}

\begin{abstract}
Nephrotic syndrome (NS) is characterized by structural changes in the actin-rich foot processes of glomerular podocytes. We previously identified high concentrations of the small heat shock protein hsp27 within podocytes as well as increased glomerular accumulation and phosphorylation of hsp27 in puromycin aminonucleoside (PAN) -induced experimental NS. Here we analyzed murine podocytes stably transfected with hsp27 sense, antisense, and vector control constructs using a newly developed in vitro PAN model system. Cell morphology and the microfilament structure of untreated sense and antisense transfectants were altered compared with controls. Vector cell survival, polymerized actin content, cell area, and hsp27 content increased after $1.25 \mu \mathrm{g} / \mathrm{ml}$ PAN treatment and decreased after $5.0 \mu \mathrm{g} / \mathrm{ml}$ treatment. In contrast, sense cells were unaffected by $1.25 \mu \mathrm{g} / \mathrm{ml}$ PAN treatment whereas antisense cells showed decreases or no changes in all parameters. Treatment of sense cells with $\mathbf{5 . 0}$ $\mu \mathrm{g} / \mathrm{ml}$ PAN resulted in increased cell survival and cell area whereas antisense cells underwent significant decreases in all parameters. Hsp27 provided dramatic protection against PAN-induced microfilament disruption in sense > vector $>$ antisense cells. We conclude that hsp27 is able to regulate both the morphological and actin cytoskeletal response of podocytes in an in vitro model of podocyte injury.-Smoyer, W. E., Ransom, R. F. Hsp27 regulates podocyte cytoskeletal changes in an in vitro model of podocyte process retraction. FASEB J. 16, 315-326 (2002)
\end{abstract}

Key Words: actin $\cdot$ stress fibers $\cdot$ nephrotic syndrome $•$ puromycin aminonucleoside

NePHROTIC SYNDROME (NS) is among the most common kidney diseases in children and frequently occurs in adults. In this disease, the kidney's filtration barrier is altered to permit massive amounts of protein to be lost in the urine, leading to low oncotic pressure in serum and resultant leakage of fluid from the bloodstream into the surrounding tissues as edema. These clinical findings correlate with dramatic structural alterations in glomerular epithelial cells (podocytes), which together with the underlying glomerular basement membrane (GBM) and endothelial cells comprise the kidney's filtration barrier. These structural changes include retraction and effacement (spreading) of the podocyte distal foot processes overlying the
GBM, disruption and redistribution of the dense accumulations of actin within these processes, and in some areas detachment of podocytes from the GBM (1-5).

The pathological mechanisms leading to NS are diverse, including immunological processes, biochemical or genetic defects, and hemodynamically induced glomerular injury (6). However, common histological features are observed in each setting, suggesting that a shared molecular mechanism mediates the podocyte structural changes characteristic of NS. One of the primary structural alterations shown to be common to both human disease and animal models of NS is the disruption of the podocyte cytoskeleton, with marked disaggregation and redistribution of actin filaments in the podocyte foot processes (7-9). Actin filaments have been reported to be the major or sole cytoskeletal protein in podocyte foot processes $(10,11)$, which suggests that the podocyte actin cytoskeleton may play a critical role in the regulation of foot process structure and function in both health and disease.

We previously reported the presence of high concentrations of the small heat shock protein hsp27 in the glomeruli of normal rats, as well as an increase in glomerular hsp27 and phosphorylation after induction of experimental NS with puromycin aminonucleoside (PAN) (12). Although the precise mechanism(s) of action of hsp27 is not yet known, it is a small stress protein reported to have important roles in resistance to thermal and metabolic stress, normal growth and differentiation, signal transduction, molecular chaperoning, and protection from apoptosis (13-20). Perhaps its best-described function, however, is that of a regulator of actin polymerization. Hsp27 has been reported to be an actin-associated protein (21) that was shown to inhibit actin polymerization in vitro (22) and in vivo (23), and its ability to inhibit actin polymerization has been correlated with its state of phosphorylation $(15,24)$.

Based on these findings we hypothesized that hsp27, via regulation of the actin cytoskeleton, has an important role in regulating both normal podocyte structure and the dramatic structural changes in podocytes that occur during NS. To begin to test this hypothesis, we

\footnotetext{
${ }^{1}$ Correspondence: Pediatric Nephrology, University of Michigan Medical Center, 8220D MSRB III, Box 0646, 1150 W. Medical Center Dr., Ann Arbor, MI 48109, USA. E-mail: rransom@umich.edu
} 
developed a model of low-concentration $(<10 \mu \mathrm{g} / \mathrm{ml})$ and long-term ( 7 days) treatment of cultured 'differentiated' podocytes with the well-described podocyte toxin PAN, followed by quantitative analyses of changes in podocyte cell survival, morphology, cell area, actin filament structure, and total filamentous actin (F-actin) content. This model was then used to quantitatively determine the specific effects of altered podocyte hsp27 levels on the podocyte response to PAN.

\section{MATERIALS AND METHODS}

\section{Cell culture}

A conditionally immortalized mouse podocyte clonal cell line (MPC-5) isolated from the 'Immortomouse' (25) was a kind gift from Dr. Peter Mundel. Proliferating podocyte cells were grown in RPMI 1640 medium containing $10 \%$ fetal bovine serum, $100 \mathrm{U} / \mathrm{ml}$ penicillin, $100 \mu \mathrm{g} / \mathrm{ml}$ streptomycin (GibcoBRL, Rockville, MD), and $10 \mathrm{U} / \mathrm{ml}$ mouse $\gamma$-interferon (Sigma, St. Louis MO) at $33^{\circ} \mathrm{C}$ with $100 \%$ relative humidity and $5 \% \mathrm{CO}_{2}$ atmosphere. Cells were induced to differentiate by transfer to $37^{\circ} \mathrm{C}$ and removal of $\gamma$-interferon from the above medium to deactivate the transgene for a thermosensitive variant of the SV40 T-antigen. All cultured podocytes used in this study were allowed to differentiate without subcultivation for 10-14 days before treatment. Twice as many antisense transfectant cells were seeded in culture dishes $(72,000$ cells/well in 6-well dish) for differentiation than vector control or sense transfectants $(36,000$ cells/well) in order to yield differentiated cultures with similar cell confluence at 10-14 days.

NIH 3T3 cells (ATCC \#CRL-1658, ATCC, Manassas, VA) and murine mesangial cells (MMC; a kind gift from Dr. Hanna Abboud) were grown in Dulbecco's modified Eagle's medium (Gibco-BRL) containing either $10 \%$ bovine calf serum (NIH-3T3) or fetal bovine serum (MMC) and 100 $\mathrm{U} / \mathrm{ml}$ penicillin and $100 \mu \mathrm{g} / \mathrm{ml}$ streptomycin at $37^{\circ} \mathrm{C}$ with $100 \%$ relative humidity and $5 \% \mathrm{CO}_{2}$ atmosphere. Cells were seeded at 20,000 cells/well of a 6-well culture dish and treated with PAN after $24 \mathrm{~h}$ in culture.

\section{Development of stably transfected podocyte clones}

Proliferating podocytes were transfected with human hsp27 sense (26), rat hsp27 antisense (27), and vector control cDNA (pcDNA3.1, Stratagene, La Jolla, CA) constructs using a transfection reagent (Superfect, Quiagen, Valencia, CA) according to the manufacturer's instructions. Stably transfected cells were selected in serial passages using G418 antibiotic at $400 \mu \mathrm{g} / \mathrm{ml}$ ( $100 \%$ lethal to untransfected podocytes). The expression vectors contained the entire protein coding region of human hsp27 placed in the sense orientation or the entire protein coding region of rat hsp27 in the antisense orientation, both inserted in the mammalian expression vector pcDNA3.1 under the control of the constitutive cytomegalovirus promoter. Clonal populations of stably transfected hsp27 sense or antisense podocyte clones were isolated by limiting dilution and selected for altered hsp27 levels. Stably transfected clones were then induced to differentiate as described above in the presence of a reduced concentration $(200 \mu \mathrm{g} / \mathrm{ml})$ of $\mathrm{G} 418$. Before treatment with PAN, cells were transferred to medium without G418.
In vitro model of podocyte process retraction

Differentiated podocyte clones were treated with a single application of PAN (Sigma) to a final concentration of 1.25 or $5.0 \mu \mathrm{g} / \mathrm{ml}$. Controls received an equivalent volume of sterile water. Cells were cultured for an additional 7 days without subcultivation. Subconfluent MMC and NIH-3T3 cells were similarly treated with PAN at concentrations identical to or markedly higher than those for podocytes. Because, in contrast to differentiated podocyte cultures, both MMC and NIH-3T3 cells proliferate continuously in culture, cells were seeded at low density and cultured for 7 days in the presence of PAN.

\section{Phase contrast microscopy}

Phase contrast microscopy was performed as described previously (28) on an inverted Zeiss Axiovert 135TV using a $20 \times$ objective lens, an 0.55 NA long-working distance condenser lens, and phase contrast optics. Images were acquired using a monochrome CCD camera (Dage model RT3000) driven by NIH Image 1.61 software and captured using a Scion LG3 image capture board installed in an Apple Macintosh computer (PowerPC 7500). Images were adjusted for contrast and gain in Adobe Photoshop v. 5.0.2.

\section{Immunohistochemistry}

After PAN treatment for 7 days, cells grown on glass coverslips were washed briefly in warm PBS and fixed in $3.7 \%$ paraformaldehyde in PBS for $30 \mathrm{~min}$. Cells were lysed by addition of an equal volume of $0.5 \%$ Triton X-100 in PBS to the fixation solution and incubation for another $5 \mathrm{~min}$. Cells were washed with $0.05 \%$ Tween-20 in PBS (T-PBS) and incubated with Texas red-conjugated phalloidin (Molecular Probes, Eugene, OR) diluted 1:250 in 5\% heat-inactivated horse serum in T-PBS for $30 \mathrm{~min}$. Coverslips were washed and mounted in $0.05 \%$ phenylenediamine in $90 \%$ glycerol in PBS and sealed with fingernail polish. Fluorescence microscopy was performed as described previously (28). Prepared cells were imaged on an inverted Zeiss Axiovert 135TV with an AtoArc 100W epifluorescent illuminator and $20 \times$ objective lens. Images were collected using an integrating monochrome CCD camera (Dage model RT3000) driven by NIH Image 1.61 software (with capture hardware described above) using macros permitting collection and signal averaging over several video frames. An average of 16 frames were integrated for fluorescent images. Images were adjusted for contrast and gain, and levels were adjusted in Adobe Photoshop v. 5.0.2. All immunofluorescence micrographs shown were taken of one of the two clones of hsp27 sense (clone 23) and hsp27 antisense (clone 9) cells, but were representative of results gathered for both clonal lines of each type.

\section{Phalloidin binding assay}

Phalloidin binding was determined using a modification of the protocol of Singhal et al. (29). After treatment, cells were washed briefly in warm PBS and fixed in $3.7 \%$ paraformaldehyde in PBS for $30 \mathrm{~min}$. Fixed cells were washed once with PBS and incubated in $0.1 \%$ saponin in PBS containing a saturating amount $(0.4 \mu \mathrm{M})$ of Texas red phalloidin for $1 \mathrm{~h}$ at room temperature in darkness with gentle agitation. Cells were washed twice with $0.1 \%$ saponin in PBS and the labeled phalloidin was extracted from cells into $1 \mathrm{ml}$ methanol by agitation for $30 \mathrm{~min}$ in darkness. The methanol was collected, centrifuged at $14,000 \mathrm{~g}$ for $5 \mathrm{~min}$ and supernatant fluorescence was measured in an LS-50B luminescence spectrometer 
(Perkin Elmer Analytical Instruments, Norwalk, CT) with excitation at $591 \mathrm{~nm}$ and emission measured at $608 \mathrm{~nm}$. Linear regression analyses of Texas red phalloidin standards was used to derive absolute amounts of bound phalloidin from each sample's relative fluorescence values. Protein was extracted from duplicate wells and assayed by the bicinchoninic acid (BCA) microassay (see below); these values were used to normalize the amount of bound phalloidin to protein quantity.

\section{Cell survival assay}

After PAN or sham treatment, culture medium was collected and the adherent cells were collected by trypsinization. The cells suspended in trypsin solution were combined with the original culture medium and cells were pelleted by centrifugation at $1500 \mathrm{~g}$ for $3 \mathrm{~min}$. The cells were resuspended in PBS and an equal volume of $0.4 \%$ trypan blue in PBS was added. After $1 \mathrm{~min}$, two aliquots of each cell suspension were counted using a hemocytometer. Cells that freely took up dye (deep blue) were scored as dead, and pale blue or clear cells were scored as live.

\section{Cell area determination}

Phase contrast micrographs $(n=6)$ were collected randomly from fixed cells after PAN treatment. The 10 cells in each digital micrograph that were entirely within the image field and closest to the arbitrary upper right-hand corner of the image were hand-traced using a graphics tablet (WACOM, Vancouver, WA) and NIH Image 1.61 software. Measurements were made of the total number of pixels within each outline and converted to unit area using a conversion factor derived from pixel measurements of a standard measure using the same microscopic optics arrangements.

\section{Protein extraction}

Proteins were extracted from cell cultures by washing adherent cells with warm PBS, followed by addition of $1 \mathrm{ml}$ per well of a 6-well tissue culture plate of 1:1 water-saturated phenol: extraction buffer. The extraction buffer consisted of $50 \mathrm{mM}$ tris-Cl pH 7.0, $700 \mathrm{mM}$ sucrose, $50 \mathrm{mM} \mathrm{KCl,} 100 \mathrm{mM} \mathrm{NaF}, 2$ $\mathrm{mM}$ each of $\mathrm{MgCl}_{2}$, EGTA, and 2-mercaptoethanol, $1 \mathrm{mM}$ sodium orthovanadate, and $0.1 \mathrm{mM}$ PMSF. Cells were extracted for $5 \mathrm{~min}$ at room temperature and the extracts centrifuged at $1500 \mathrm{~g}$ for $15 \mathrm{~min}$ at $10^{\circ} \mathrm{C}$ to separate phases. The upper, phenol phase was removed and mixed with 5 vol of $-20^{\circ} \mathrm{C}$ methanol acidified with $100 \mathrm{mM}$ ammonium acetate. After precipitation of protein overnight at $-20^{\circ} \mathrm{C}$, precipitates were collected by centrifugation at $1500 \mathrm{~g}$ for $25 \mathrm{~min}$ at $4^{\circ} \mathrm{C}$. Pellets were washed twice with ice-cold $80 \%$ methanol and dried under vacuum. Protein was solubilized from dried pellets in a minimal volume of $2 \%$ SDS, $62.5 \mathrm{mM}$ tris-Cl $\mathrm{pH}$ $6.8,10 \%$ glycerol for SDS-PAGE analysis or into isoelectric focusing (IEF) sample buffer (9 M urea, 2\% (w/v) Nonidet P-40, $50 \mathrm{mM} \mathrm{NaF}, 5 \mathrm{mM}$ sodium orthophosphate, $67 \mathrm{mM}$ $[\beta-\mathrm{D}]$ glycerophosphate $\mathrm{pH} 7.2,1 \mathrm{mM}$ sodium orthovanadate, $1 \mathrm{mM}$ EDTA, 2\% 2-mercaptoethanol, $0.1 \mathrm{mM}$ PMSF, and $0.5 \mu \mathrm{g} / \mathrm{ml}$ each of leupeptin, pepstatin, and aprotinin) by prolonged, gentle agitation. The protein content in SDSPAGE samples was determined using the BCA microassay.

\section{SDS-PAGE, slab IEF separations, and Western blotting}

SDS-PAGE sample buffer extracts containing equal quantities of protein from each sample were brought to $5 \%$ 2-mercap- toethanol, heated to $100^{\circ} \mathrm{C}$ for $4 \mathrm{~min}$, and separated on $13 \%$ polyacrylamide gels by SDS-PAGE, followed by transfer to PVDF membranes by immersion blotting. Urea buffer protein extracts containing similar amounts of hsp27 (as determined by prior analysis of SDS-PAGE sample buffer extracts by quantitative Western blotting) were separated by slab-gel IEF using the Bio-Rad Model 111 Mini-IEF Cell essentially according to the manufacturer's instructions, except that the support film was omitted to permit subsequent transfer of proteins to PVDF membranes. Proteins were focused at $100 \mathrm{~V}$ for $15 \mathrm{~min}, 200 \mathrm{~V}$ for $15 \mathrm{~min}$, and finally at $450 \mathrm{~V}$ for 1 to $2 \mathrm{~h}$. After focusing, proteins were transferred to PVDF membranes by semi-dry transfer for $30 \mathrm{~min}$ at $75 \mathrm{~mA}$.

Protein binding sites on PVDF membranes were blocked with $5 \%$ nonfat dry milk in T-PBS overnight at $4^{\circ} \mathrm{C}$. Membranes were incubated with primary antibodies [1:5000 rabbit anti-murine hsp27 polyclonal or mouse anti-human hsp27 monoclonal (StressGen, Victoria, BC, Canada)] in 5\% BSA in T-PBS for $1 \mathrm{~h}$ at room temperature. After three washes, blots were incubated in secondary antibody solution [1:10,000 goat anti-rabbit IgG horseradish-peroxidase conjugate or 1:5000 goat anti-mouse IgG horseradish-peroxidase conjugate (Jackson ImmunoResearch, West Grove, PA)] in 5\% nonfat dry milk in PBS-T for $1 \mathrm{~h}$ at room temperature. After three additional washes, antibody binding was visualized using the ECL chemiluminescence system (Amersham, Arlington Heights, IL) as detected using the Bio-Rad Chemidoc system (Bio-Rad, Hercules, CA). Densitometric analyses of captured images were performed using version 4.1.0.026 of the Bio-Rad Quantity One software. Quantitation of the absolute amounts of specific protein in each band was performed by linear regression analysis using six different amounts of standard protein (murine or human hsp27; StressGen) on each blot to generate standard curves of protein content vs. densitometric units (mean density value $\times$ area).

\section{Protein assay}

The BCA protein microassay (30) was used to quantify total protein in samples. Equal volumes of sample solubilization buffer were added to albumin protein standards to normalize for the effect of buffer components on the assay results.

\section{Statistics}

Results were analyzed for statistical significance using Statview v. 4.57 software (Abacus Concepts, Berkeley, CA) by the unpaired, two-tailed $t$ test. Comparisons with $P$ values $<0.05$ were considered significant and $P$ values $<0.01$ were separately noted. Separate statistical analyses were performed to compare PAN-treated vs. sham-treated individual transfectant clones $(* P<0.05$ and $* * P<0.01$ vs. sham-treated cells) and to compare PAN-treated and sham-treated vector control cells with the combined results from both clones of similarly treated hsp27 sense or antisense transfectants $(+P<0.05$, $++P<0.01$ vs. vector cells).

\section{RESULTS}

\section{Podocyte treatment with PAN induces variable Hsp27 accumulation}

Protein extracts from untransfected podocytes differentiated for 10-14 days followed by PAN treatment for 7 days were analyzed by quantitative Western blotting 
using an anti-murine hsp27 antibody. Podocytes treated with a low dose of PAN $(1.25 \mu \mathrm{g} / \mathrm{ml})$ had a significant accumulation of hsp27 (230 $13 \%$ of hsp27 content in time-matched, sham-treated control cells) and podocytes treated with high-dose PAN $(5.0 \mu \mathrm{g} / \mathrm{ml})$ had a

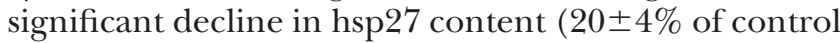
hsp27 value). These findings demonstrated that lowdose PAN treatment induces accumulation of endogenous hsp27 in cultured podocytes and are consistent with our previously reported findings of hsp27 accumulation in glomeruli after PAN-induced NS in animals (12).

\section{Stable podocyte transfectants contain dramatically different amounts of Hsp27}

Protein extracts of independently cloned podocyte cell lines stably transfected with either human hsp27 sense (sense) or rat hsp27 antisense (antisense) constructs and differentiated for 10 days were analyzed by quantitative Western blotting using anti-human hsp27 or anti-murine hsp27 antibodies. These reagents allowed independent analysis of the human or murine hsp27 isoforms without interspecies cross-reaction. Vector control podocytes contained $2.34 \mathrm{ng}$ of murine hsp27/ $\mathrm{gg}$ protein (Fig. 1) and, as expected, no detectable human hsp27 (data not shown). Both sense clones had significantly greater amounts of human hsp27 (17.1 and $14.9 \mathrm{ng} \mathrm{hsp27/ \mu g}$ protein in clones 23 and 31 , respectively) than the amount of murine hsp27 in vector controls whereas both antisense clones contained significantly smaller amounts of murine hsp27 (0.41 and $0.21 \mathrm{ng} \mathrm{hsp27/ \mu g}$ protein in clones 9 and 20, respectively) than vector-transfected cells (Fig. 1). No endogenous murine hsp27 protein was detected (limit of detection $\sim 0.02 \mathrm{ng} / \mu \mathrm{g}$ protein) in sense clones (data not shown). The mean amount of hsp27 present in all sense clones combined was $>680 \%$ of vector control values whereas the mean quantity of hsp27 in antisense clones was only $13 \%$ of vector control values, equivalent to a 51-fold difference in hsp27 expression between sense and antisense clones.

\section{Stable podocyte transfectants have less Hsp27 phosphorylation than vector transfectants}

Protein extracts from differentiated vector control cells or sense or antisense clones were separated by IEF, followed by Western blotting to determine the relative amount of hsp27 phosphorylation. Only monophosphorylated and unphosphorylated hsp27 isoforms were detected in extracts of transfectants, despite two possible serine phosphorylation sites on murine hsp27 and three possible sites on human hsp27 (31). The percentage of hsp27 phosphorylated was greater in vector control cells $(30 \%)$ than in antisense clone $9(21 \%)$ or in either of the sense clones (13\% and $17 \%$ in clones 23 and 31, respectively), as shown in Fig. 2. When the results from individual clones were combined and analyzed in aggregate, there was significantly more

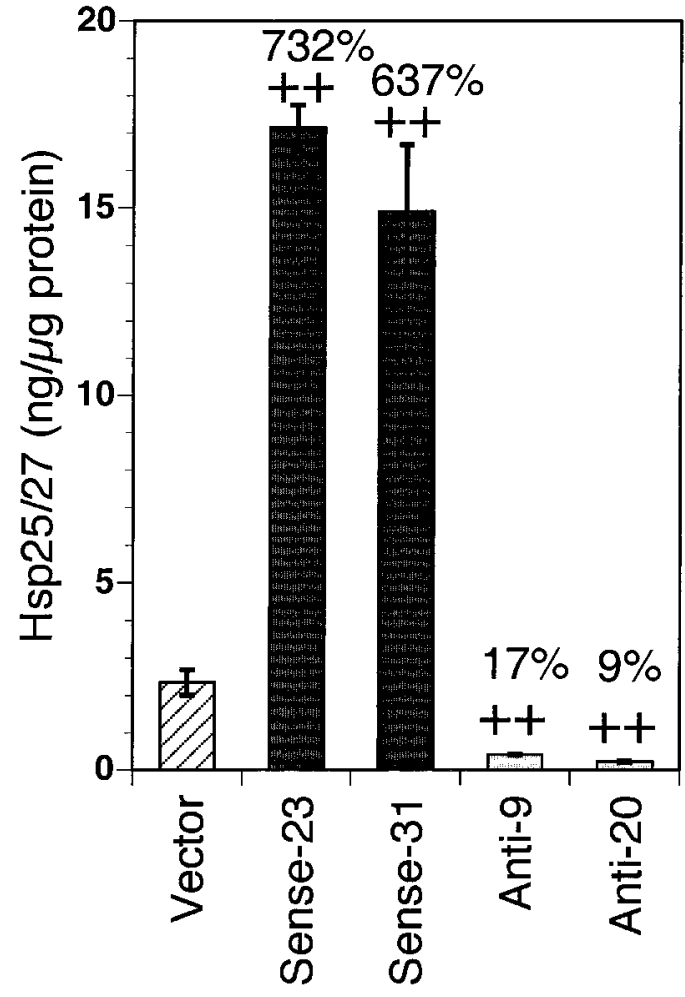

Figure 1. Stable podocyte transfectants express markedly different amounts of hsp27. The results of quantitative Western blotting analyses for murine or human hsp27 in differentiated podocyte clones transfected with vector alone, human hsp27 sense, and rat hsp27 antisense constructs are shown. Both sense clones (dark gray bars) and both antisense clones (light gray bars) expressed significantly different amounts of hsp27 than vector controls (hatched bar). Percentage values express the amount of human hsp27 in sense clones or murine hsp27 in antisense clones as a percentage of the amount of murine hsp27 in vector controls. No murine hsp27 was detected in human sense clones; as expected, no human hsp27 was detected in vector or hsp27 antisense clones (data not shown $)(n=4 ; \mathrm{x} \pm \mathrm{SE} ;++P<0.001$ vs. vector control cells $)$.

phosphorylated hsp27 in vector cells than in either antisense or sense clones. Aggregate significance values were determined by comparing vector values $(n=4$, mean $=30 \%)$ with combined antisense $(n=8$, four each of clones 9 and 20 , mean $=23 \%)$ or sense $(n=8$, four each of clones 23 and 31 , mean $=15 \%$ ) values. These results demonstrated that in murine podocyte transfectants, both the endogenous murine hsp27 in vector and antisense transfectants and the exogenous human hsp27 in sense transfectants are phosphorylated.

Because the absolute amounts of phosphorylated and unphosphorylated hsp27 present in cells may be more biologically relevant than percentage of phosphorylated hsp27, absolute quantities of phosphorylated and unphosphorylated hsp27 (Table 1) in each podocyte clone were calculated from the data shown in Figs. 1 and 2. This analysis revealed that although a smaller percentage of the hsp27 in sense clones was phosphorylated than in vector controls (Fig. 2), the absolute amount of phosphorylated hsp27 in sense cells was $>$ threefold greater than the amount in vector 


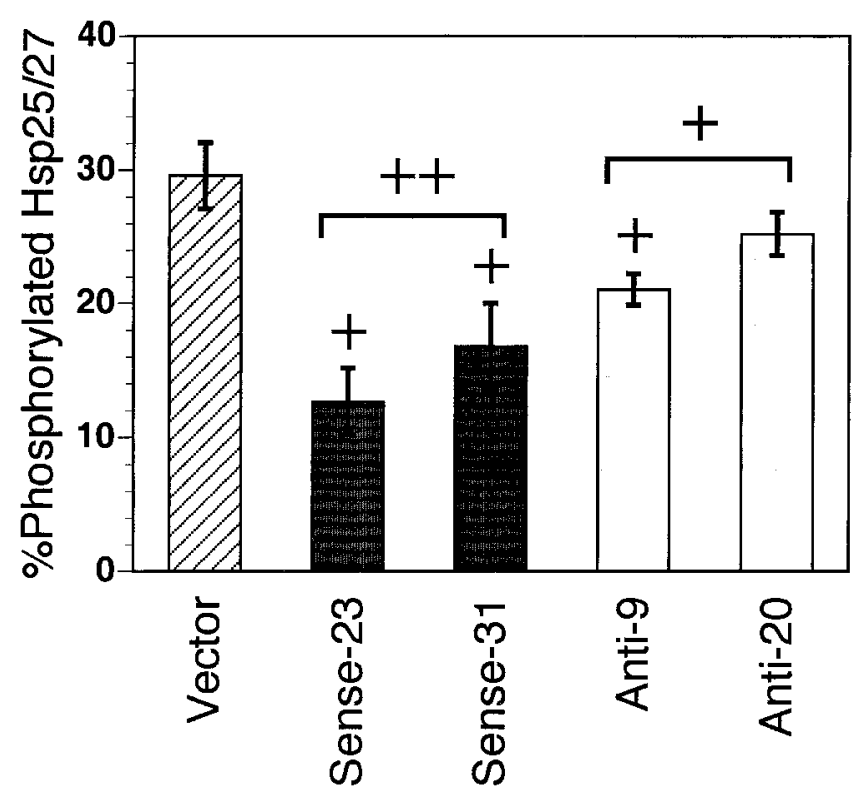

Figure 2. Stable podocyte transfectants have less hsp27 phosphorylation than do vector transfectants. The results of IEF separation and Western blot analyses of extracts from differentiated podocyte clones transfected with vector alone, hsp27 sense, or hsp27 antisense constructs are expressed as \% phosphorylated hsp27 (ratio of monophosphorylated isoform to total of phosphorylated and unphosphorylated hsp27 expressed as a percentage). The percentage of phosphorylated hsp27 in both sense clones (dark gray bars), singly and in aggregate, was significantly less than the percentage of phosphorylated hsp27 in vector control cells (hatched bar). Similarly, the percentage of phosphorylated hsp27 in antisense clone 9 and in the aggregate of both antisense clones (light gray bars) was significantly less than vector values $(n=4$; $\mathrm{x} \pm \mathrm{SE} ;+P<0.05,++P<0.001$ vs. vector control cells).

controls (>2.2 ng/ $\mu$ g vs. $0.7 \mathrm{ng} / \mu \mathrm{g}$; Table 1$)$. In contrast, both the percentage and absolute amount of phosphorylated hsp27 in antisense clones were less than the corresponding values in vector controls (Fig. 2 and Table 1). Similarly, the amount of unphosphorylated hsp27 in sense transfectants was $>$ sixfold greater than the amount in vector controls and $\sim$ sixfold more unphosphorylated hsp27 was present in vector controls than in antisense clones. The finding that a smaller percentage but larger absolute amount of hsp27 is phosphorylated in sense transfectant clones vs. vector controls and that there is a larger absolute amount of unphosphorylated hsp27 in sense (and lesser amount in antisense) than vector controls raises the possibility that the observed phenotypic differences between transfectants and controls (see below) may be due to differences in either the amount of total hsp27 (Fig. 1) or the amount of a particular phosphorylated isoform of hsp27 (Table 1).

\section{Hsp27 regulates normal podocyte morphology and PAN-induced morphological changes}

Differentiated sense and antisense clones displayed dramatically different cellular morphologies compared with vector controls as examined by phase contrast microscopy (Fig. 3). Untreated, differentiated vector control cells displayed a characteristic flattened morphology with numerous cell processes (Fig. 3A) whereas untreated sense clones were often elongated, with smooth cell borders and many contiguous areas of cell-cell contact (Fig. 3D); antisense clones were flattened but exhibited less frequent and smaller processes than controls (Fig. 3G).

Vector and sense cell morphology was largely unchanged after treatment with $1.25 \mu \mathrm{g} / \mathrm{ml}$ PAN (Fig. 3B, $E)$ whereas many antisense cells had partially retracted and some cells had detached (Fig. 3H). After treatment with $5.0 \mu \mathrm{g} / \mathrm{ml} \mathrm{PAN}$, the majority of attached vector and antisense cells retracted (Fig. $3 C, I$ ) and the vast majority of antisense cells detached and died (data not shown). In marked contrast, sense cells (Fig. 3F) displayed relative morphological preservation after PAN treatment vs. either vector control (Fig. 3C) or antisense (Fig. 3I) cells. These results indicated that hsp27 was able to both alter normal podocyte morphology and modulate PAN-induced podocyte morphological changes.

\section{Hsp27 regulates podocyte cell survival after PAN treatment}

Trypan blue assays after treatment revealed there were no significant differences in the number of nonvital cells (cells that took up dye) either between vector control, sense, and antisense transfectants or between untreated and PAN-treated cells. In all cell suspensions regardless of hsp27 protein expression or treatment, $\sim 10 \%$ of cells were dead (data not shown). Cell counts of living cells, however, showed that stable transfection and PAN treatment both influenced the number of vital cells remaining in podocyte cultures after differentiation and treatment. Approximately half of the number of vector control cells initially seeded into plates $\left(3.6 \times 10^{4}\right)$ were present after differentiation and sham treatment $\left(1.8 \times 10^{4}\right.$, Fig. $4 A$, left bar $)$. There were significantly more live vector cells present in cultures treated with $1.25 \mu \mathrm{g} / \mathrm{ml}$ PAN than in untreated cultures, but significantly fewer after treatment with 5.0 $\mu \mathrm{g} / \mathrm{ml}$ PAN (Fig. $4 A$ ). In contrast, the number of live

TABLE 1. Hsp27 phospho-isoforms in podocyte transfectants ${ }^{a}$

\begin{tabular}{lcc}
\hline \hline Transfectant & Unphosphorylated $^{b}$ & Monophosphorylated $^{c}$ \\
\hline Vector & 1.67 & 0.70 \\
Sense Clone 23 & 14.9 & 2.22 \\
Sense Clone 31 & 12.4 & 2.53 \\
Antisense Clone 9 & 0.32 & 0.09 \\
Antisense Clone 20 & 0.16 & 0.05 \\
\hline
\end{tabular}

${ }^{a}$ The absolute amount of un- or monophosphorylated hsp27 in stably transfected, differentiated podocytes was derived from the quantitation of total hsp27 (Fig. 1) and the percentage of phosphorylated hsp27 (Fig. 2). ${ }^{b}$ Nanograms of unphosphorylated $\mathrm{hsp} 27 / \mu \mathrm{g}$ total cellular protein. $\quad{ }^{c}$ Nanograms of monophosphorylated $\mathrm{hsp} 27 / \mu \mathrm{g}$ total cellular protein. 
Figure 3. Hsp27 regulates normal podocyte morphology and the morphological changes induced by PAN. Phase contrast micrographs of vector control $(A-C)$, hsp27 sense $(D-F)$, and hsp27 antisense $(G-I)$ transfectants are shown after treatment for 7 days with $0 \mu \mathrm{g} / \mathrm{ml}(A, D$, $G), 1.25 \mu \mathrm{g} / \mathrm{ml}(B, E, H)$, or 5.0 $\mu \mathrm{g} / \mathrm{ml}(C, F, I)$ PAN. Micrographs of only one clone each of sense (clone 23) or antisense (clone 9) transfectants are shown, but are representative of results obtained with both clones. White bar in lower right corner $=40 \mu$.
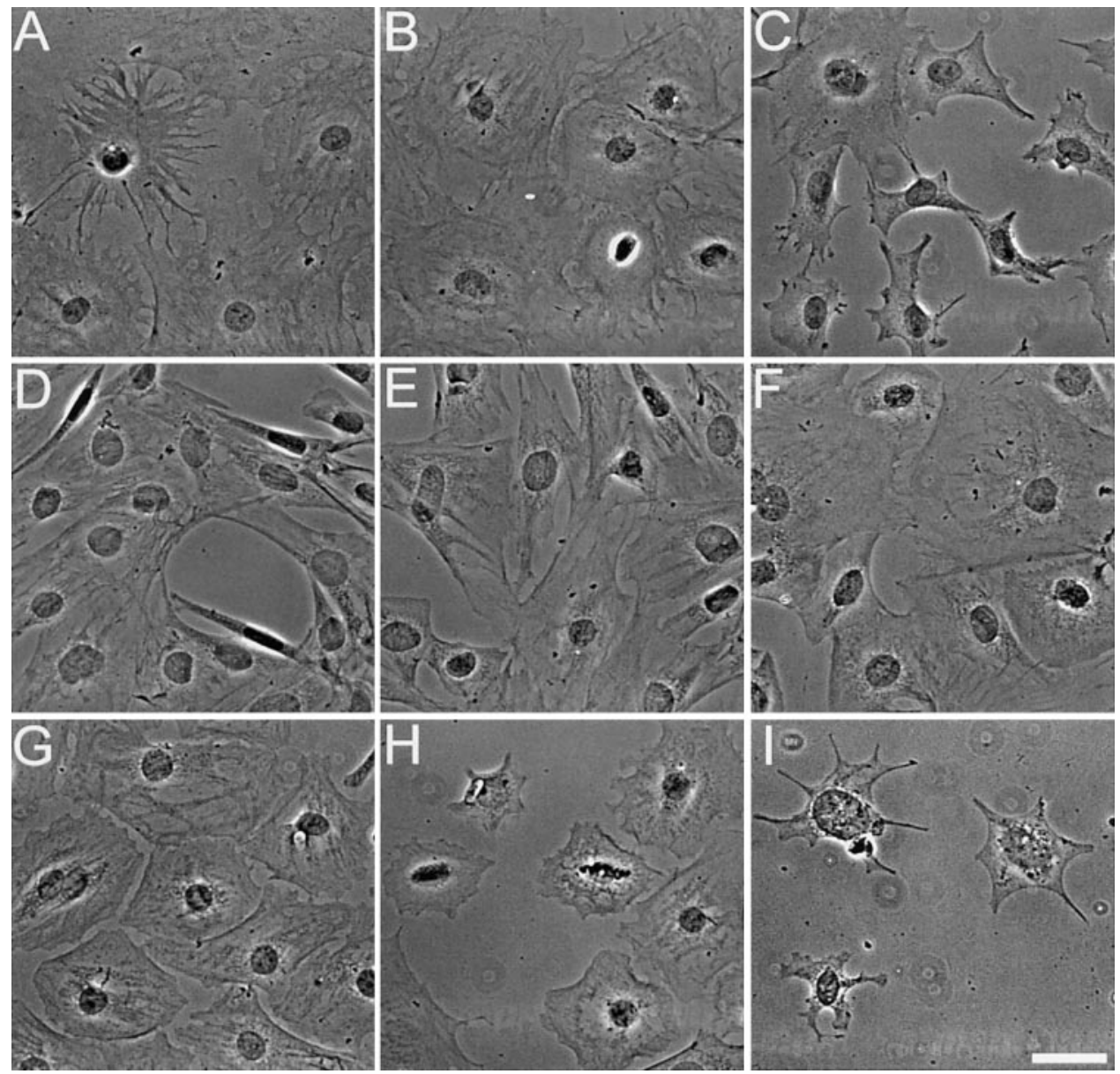

sense clone 31 cells increased significantly vs. untreated sense cells at both PAN concentrations (Fig. $4 B$, right bars) whereas the number of live sense clone 23 cells increased significantly only after treatment with 5.0 $\mu \mathrm{g} / \mathrm{ml}$ PAN (Fig. $4 B$, left bars). In marked contrast to sense clones and vector control cells, a significant decline in the number of live antisense clone 20 cells was observed after $1.25 \mu \mathrm{g} / \mathrm{ml}$ PAN treatment (Fig. $4 C$, right bars), and both antisense clone populations dramatically declined compared with untreated controls after $5.0 \mu \mathrm{g} / \mathrm{ml}$ PAN treatment.

When compared with identically treated vector con- trol cells, the mean number of sense cells (results from both clones in aggregate) was significantly greater in sham-treated controls (mean of $2.8 \times 10^{4}$ sense cells vs. $1.8 \times 10^{4}$ vector control cells) and after PAN treatment at either concentration (Fig. $4 B$ vs. $A$ ). In contrast, even though cultures were initially seeded with twice as many antisense cells $\left(7.2 \times 10^{4}\right)$, when considered in aggregate there were no significant differences between vector controls and antisense clones after sham treatment or treatment with PAN at $1.25 \mu \mathrm{g} / \mathrm{ml}$ (Fig. $4 C$ vs. $A$ ). Notably, however, the number of antisense cells remaining after treatment with $5.0 \mu \mathrm{g} / \mathrm{ml}$ PAN was

Figure 4. Hsp27 regulates podocyte cell survival after PAN treatment. Cell survival determinations for differentiated podocyte clones transfected with vector alone $(A)$, hsp27 sense $(B$; left bars $=$ clone 23 , right bars $=$ clone 31$)$, or hsp27 antisense $(C$; left bars $=$ clone 9 , right bars $=$ clone 20) constructs are shown after treatment for 7 days with $0,1.25$, or $5 \mu \mathrm{g} / \mathrm{ml} \mathrm{PAN}$. Vector control and sense clones were seeded at 36,000 cells/well whereas twice as many antisense clones were initially seeded to result in a similar cell density

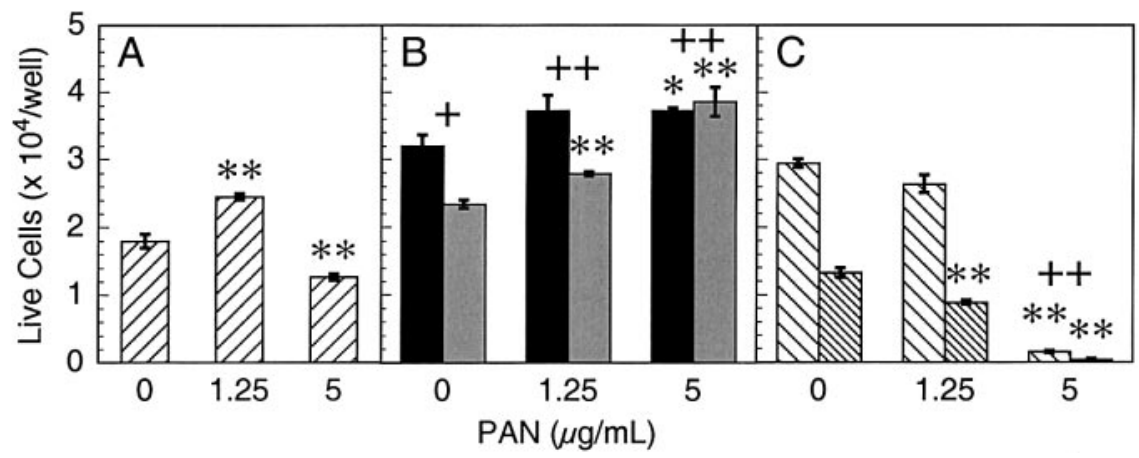
after differentiation. After differentiation for 10 days, cells were treated for 7 days, trypsinized, and assayed for vitality with trypan blue yielding counts of live (excluded dye) and dead cells. Only live cell counts are plotted, since $\sim 10 \%$ of total cells were dead in each treatment $(n=3$; \pm \pm se; $* P<0.05, * * P<0.01$ vs. untreated control cells; $+P<0.05,++P<0.01$ vs. vector control cells). 


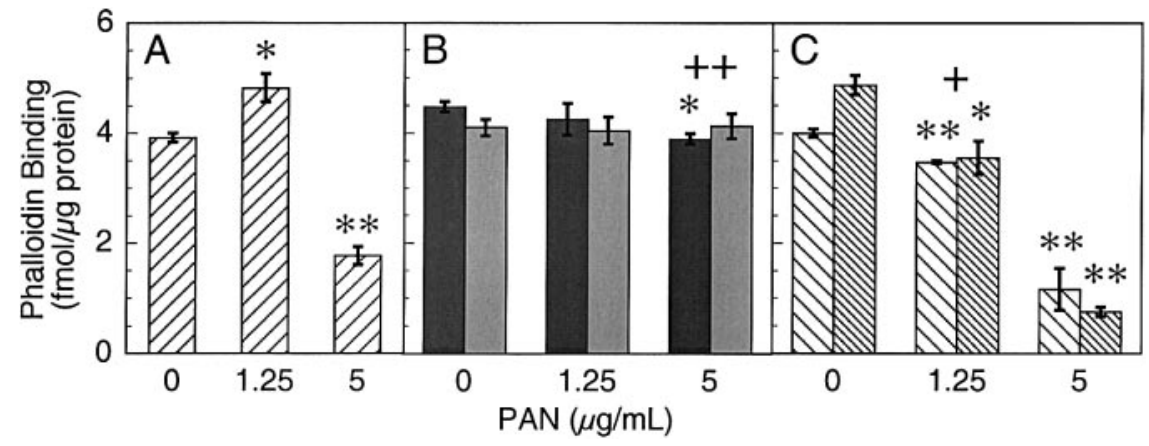

Figure 5. Hsp27 regulates podocyte polymerized actin content after PAN treatment. The results of phalloidin binding assays as a quantitative, normalized measure of polymerized cellular actin (fmol phalloidin bound per $\mu \mathrm{g}$ of total protein) are shown in differentiated podocyte clones transfected with vector alone $(A)$, hsp27 sense $(B$; left bars $=$ clone 23 , right bars $=$ clone 31$)$, and hsp27 antisense $(C$; left bars $=$ clone 9 , right bars $=$ clone 20) constructs after treatment for 7 days with $0,1.25$, or $5 \mu \mathrm{g} / \mathrm{ml}$ PAN. After differentiation, cells were treated for 7 days with PAN, fixed, and incubated with a saturating quantity of Texas red phalloidin. Bound phalloidin was extracted into methanol and quantified by fluorescence spectroscopy $(n=3$; $\mathrm{x} \pm \mathrm{sE} ; * P<0.05$, $* * P<0.01$ vs. untreated control cells; $+P<0.05,++P<0.01$ vs. vector control cells).

significantly less than identically treated vector controls (Fig. $4 C$ vs. $A$ ). These results confirmed the ability of hsp27 to influence podocyte cell survival during differentiation as well as modulating the response to PAN treatment.

\section{Hsp27 regulates podocyte polymerized actin content after PAN treatment}

Since disruption of podocyte actin filaments is a characteristic feature of NS and hsp27 is a known regulator of actin polymerization, the amount of phalloidin bound by podocytes was assayed to provide a quantitative measure of the amount of polymerized actin present in cells. We found a significant increase in the polymerized actin content of vector cells after treatment with $1.25 \mu \mathrm{g} / \mathrm{ml}$ PAN vs. untreated controls and a significant decrease after $5.0 \mu \mathrm{g} / \mathrm{ml}$ PAN (Fig. 5A). In contrast, there was no significant change in phalloidin binding in either sense clone after PAN treatment except for a slight decrease in sense clone 23 after treatment at $5.0 \mu \mathrm{g} / \mathrm{ml}$ (Fig. $5 B$, left bars), whereas both antisense clones displayed a significant decrease in phalloidin binding compared with untreated cells after PAN treatment at both concentrations (Fig. 5C).

Combined phalloidin binding assay results from both sense or both antisense clones in aggregate were also compared with identically treated vector controls. After treatment with $5.0 \mu \mathrm{g} / \mathrm{ml}$ PAN, significantly more phalloidin was bound by sense cells than vector controls (Fig. $5 B$ vs. $A$ ) whereas antisense cells bound less phalloidin than vector controls after 1.25 (Fig. $5 C$ vs. $A$ ) and similar amounts after $5.0 \mu \mathrm{g} / \mathrm{ml}$ PAN treatment. Since phalloidin binding represents a measure of cellular polymerized actin, these results indicated clearly that sense clones were significantly more resistant to PAN-induced disruption of podocyte actin filaments than either vector control or antisense cells.

\section{Hsp27 regulates both normal podocyte actin cytoskeleton and the changes induced by PAN}

Figure 6 shows representative micrographs of the structure of actin filaments as revealed by fluorescent phalloidin labeling in cells after differentiation and PAN treatment. Untreated vector control cells (Fig. $6 A$ ) contained central, regular arrays of large actin stress fibers surrounded by a peripheral region containing mostly smaller actin filaments. Cellular processes contained actin filaments, but not exclusively in the form of large stress fibers. In contrast, untreated sense clones (Fig. 6D) contained abundant, parallel arrays of comparatively thin actin stress fibers that extended across the entire cell body. Untreated antisense clones (Fig. 6G) contained a mixture of large and smaller stress fibers, often with a central bundle of large stress fibers and smaller peripheral stress fibers.

After treatment with PAN at $1.25 \mu \mathrm{g} / \mathrm{ml}$, actin filaments in vector control cells (Fig. 6B) were partially disrupted, with large stress fibers spread more diffusely than in untreated cells; strongly staining, punctate concentrations of polymerized actin appeared in cells. At the higher PAN concentration (Fig. 6C), the large stress fibers had almost completely disappeared, though finer actin filaments were still visible in the cell body, often arranged in a circular pattern. The punctate actin concentrations were more prominent than at $1.25 \mu \mathrm{g} / \mathrm{ml}$ PAN. In contrast to these changes, actin filaments in PANtreated sense clones were largely unaffected by PAN treatment at either concentration (Fig. 6E, F), although some subcortical and punctate concentrations of polymerized actin were visible in sense cells treated with $5.0 \mu \mathrm{g} / \mathrm{ml}$ PAN (Fig. 6F). Compared with either the vector control or sense clones, the actin cytoskeleton in antisense clones was more severely disrupted by PAN. Treatment with the lower PAN dosage $(1.25 \mu \mathrm{g} / \mathrm{ml})$ caused loss of most large stress fibers (Fig. 6H). After treatment with 5.0 $\mu \mathrm{g} / \mathrm{ml}$ PAN (Fig. 6I), large stress fibers essentially disappeared from the few remaining antisense cells, leaving only a thin subcortical ring of polymerized actin and fine actin filaments in the cell body. Similar to the phalloidin binding results above, these results clearly demonstrated that hsp27 was able to modulate PAN-induced disruption of podocyte actin filaments. 
Figure 6. Hsp27 regulates both the normal podocyte actin cytoskeleton and the changes induced by PAN. Immunofluorescence micrographs of Texas red phalloidin staining of actin filaments in vector control $(A-C)$, hsp27 sense $(D-F)$, and hsp27 antisense $(G-I)$ transfectants are shown after treatment for 7 days with $0 \mu \mathrm{g} / \mathrm{ml}(A, D, G)$, $1.25 \mu \mathrm{g} / \mathrm{ml}(B, E, H)$, or 5.0 $\mu \mathrm{g} / \mathrm{ml}(C, F, I)$ PAN. Micrographs of only one clone each of sense (clone 23) or antisense (clone 9) transfectants are shown but are representative of results obtained with both clones. White bar in lower right corner $=40 \mu$.
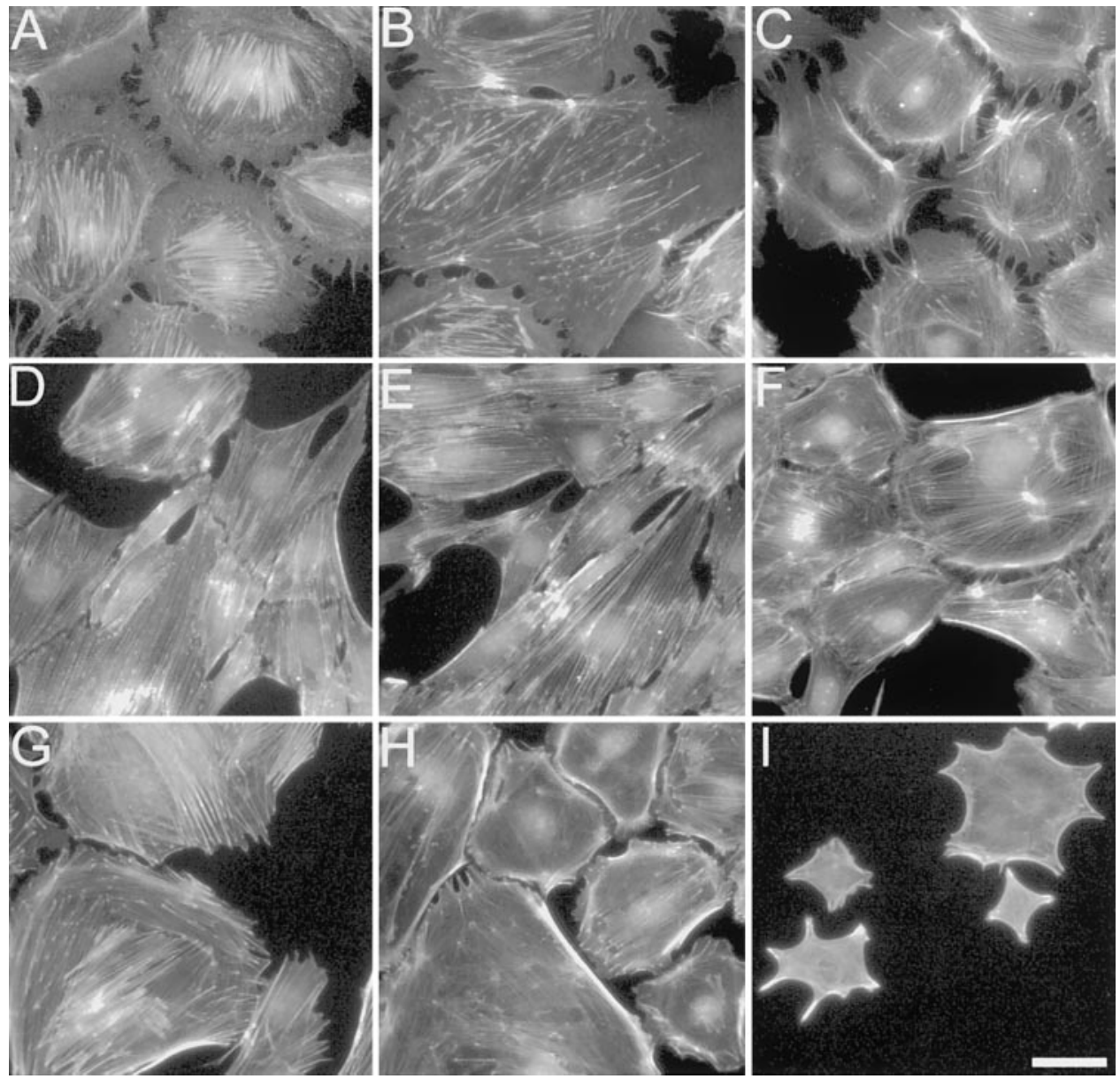

\section{Hsp27 regulates podocyte cell area changes induced by PAN treatment}

Digital phase contrast micrographs of transfectants were analyzed to determine cell area by manually outlining cell borders and integrating the enclosed area. The mean cell area of vector control cells treated with $1.25 \mu \mathrm{g} / \mathrm{ml}$ PAN was significantly greater than sham-treated cells whereas the mean cell area was significantly smaller in vector cells treated with 5.0 $\mu \mathrm{g} / \mathrm{ml}$ PAN (Fig. 7A). There were no significant changes in mean cell area in the sense clones after treatment with $1.25 \mu \mathrm{g} / \mathrm{ml}$ PAN whereas treatment with $5.0 \mu \mathrm{g} / \mathrm{ml}$ PAN caused a significant increase in cell area in both clones (Fig. $7 B$ ). The changes in mean cell area of antisense clone 9 in response to PAN treatment were similar to the responses of vector control cells whereas the area of clone 20 cells showed no significant change after $1.25 \mu \mathrm{g} / \mathrm{ml}$ PAN treatment and a significant decrease after $5.0 \mu \mathrm{g} / \mathrm{ml}$ PAN treatment.

When analyzed in aggregate, only sense clones displayed significant differences in mean cell area vs. identically treated vector control cells. Sense clones were significantly smaller than vector controls after 1.25

Figure 7. Hsp27 regulates podocyte cell area changes induced by PAN treatment. The results of cell area determinations are shown for differentiated podocytes stably transfected with vector alone $(A)$, hsp27 sense $(B$; left bars $=$ clone 23 , right bars $=$ clone 31$)$, and hsp27 antisense $(C$; left bars $=$ clone 9 , right bars $=$ clone 20) constructs after treatment for 7 days with $0,1.25$, or $5 \mu \mathrm{g} / \mathrm{ml}$ PAN. Cell surface area for each cell type was determined by outlining the edges of the 10 cells closest to the arbitrary upper right corner and entirely within each of 6 ran-

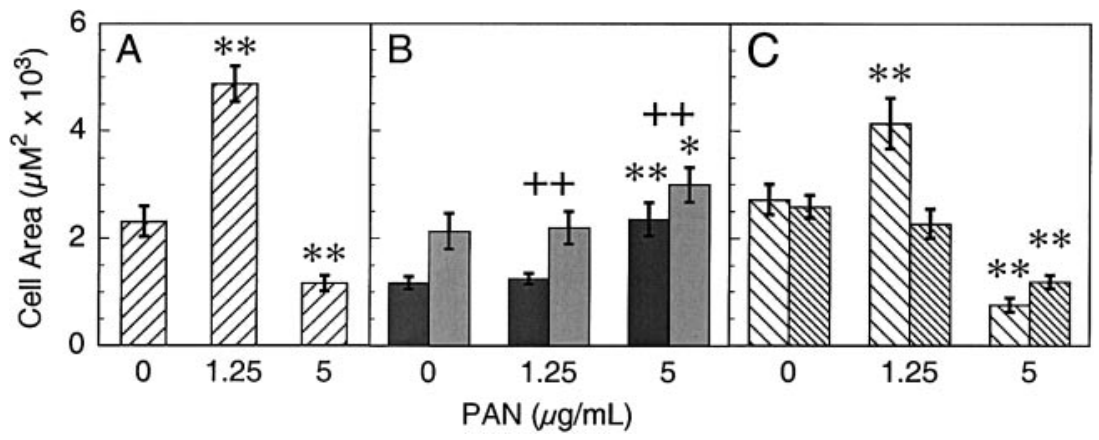
domly selected images and calculating total cell area from the number of pixels enclosed by the outlines $(n=60$ (vector) or 120 (60 of each sense or antisense clone) cells per group; $\mathrm{x} \pm \mathrm{SE} ; * P<0.05, * * P<0.01$ vs. untreated control cells; $++P<0.01$ vs. vector control cells). 
$\mu \mathrm{g} / \mathrm{ml}$ PAN treatment and significantly larger than controls after treatment with $5.0 \mu \mathrm{g} / \mathrm{ml}$ PAN (Fig. $7 B$ vs. A). These results together clearly indicated hsp27 was able to modulate PAN-induced changes in cultured podocyte cell area.

\section{PAN effects on cell morphology and actin cytoskeleton are relatively podocyte specific}

To determine the cell specificity of the effects of PAN observed in murine podocytes, we treated both NIH3T3 fibroblasts and kidney MMC with various concentrations of PAN. We found that the morphology of both MMC and NIH-3T3 cells was unaffected by culture in the presence of $1.25 \mu \mathrm{g} / \mathrm{ml}$ PAN (compare Fig. 8A, $\boldsymbol{B}$ with $C$ and $D$, respectively). Treatment of either cell type with $5.0 \mu \mathrm{g} / \mathrm{ml}$ PAN resulted in a more flattened cell morphology (Fig. 8E, $F$ ) as well as partial disruption of actin filaments and increased cell area (data not shown), similar to the results observed in differentiated podocytes after treatment with $1.25 \mu \mathrm{g} / \mathrm{ml}$ PAN. The retraction, detachment, and severe actin filament disruption observed in differentiated podocytes after treatment with $5.0 \mu \mathrm{g} / \mathrm{ml}$ PAN were observed in MMC cells only after treatment with $25 \mu \mathrm{g} / \mathrm{ml}$ PAN (Fig. 8G) and in NIH-3T3 cells at a PAN concentration $>25 \mu \mathrm{g} / \mathrm{ml}$ (Fig. 8H). These results suggest that differentiated, cultured podocytes are specifically affected by concentrations of PAN that do not affect other cell types, in agreement with the earlier observation that podocytes derived from primary glomerular outgrowths are highly sensitive to PAN treatment (32).

\section{DISCUSSION}

We previously reported that the small heat shock protein hsp27 is present at high levels in the glomerular podocyte and that hsp27 mRNA expression, protein quantity, and protein phosphorylation are all increased in the glomeruli of rats with PAN-induced NS (12). In the present study, we tested the hypothesis that hsp27 has an important role in regulating normal podocyte structure and the dramatic structural changes in podocytes that occur during NS. To do this, we developed cultured podocyte clones stably transfected with sense and antisense hsp27 constructs and analyzed the effects of altered hsp27 levels using a newly developed in vitro model of PAN-induced podocyte injury.

These studies used cultured podocytes derived from the 'Immortomouse', which conditionally expresses the SV40 T-antigen to permit growth as 'differentiated' podocytes expressing differentiation-specific protein markers and displaying a flattened morphology, distinctive cellular processes, and a low cell proliferation rate (25). Although these differentiated podocytes do not form the extensive interdigitating networks of secondary cell processes spanned by slit membranes characteristic of podocytes in vivo, they do have several fundamental characteristics of in vivo podocytes that
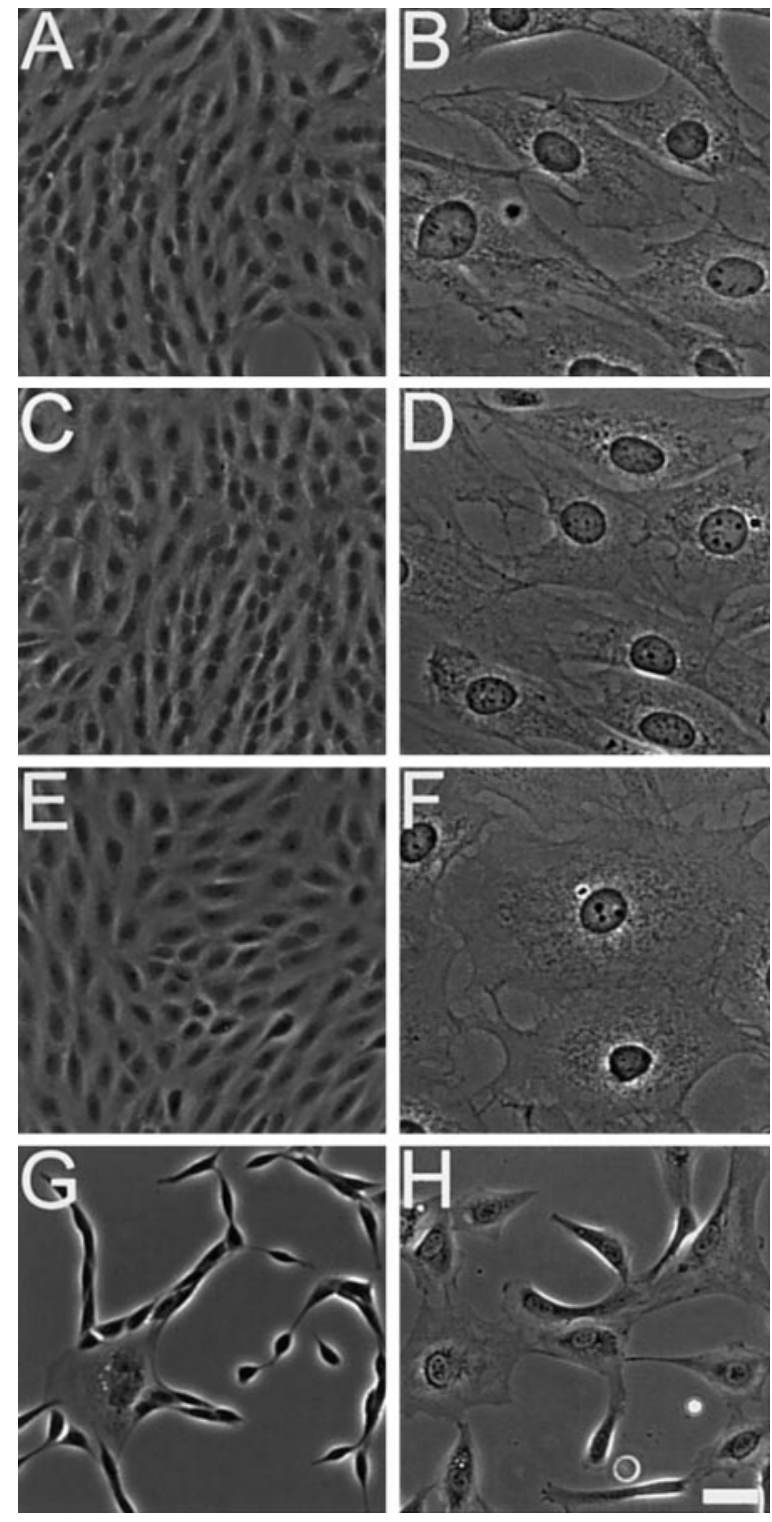

Figure 8. PAN does not affect MMC or NIH-3T3 cell morphology or actin cytoskeleton. Phase contrast micrographs of mouse mesangial cells $(A, C, E, G)$ or NIH-3T3 cells $(B, D, F$, $H$ ) treated for 7 days with $0(A, B), 1.25(C, D), 5.0(E, F)$, or $25(G, H) \mu \mathrm{g} / \mathrm{ml}$ PAN. White bar in lower right corner $=$ $40 \mu$.

were lacking in earlier podocyte culture systems; at this time they represent the best available in vitro cell culture system for analysis of podocyte responses to relevant effectors such as PAN. We analyzed changes in podocyte morphology and actin cytoskeleton after 7 days of PAN treatment, a time selected to closely model the time of the most dramatic podocyte structural changes in PAN-induced NS in vivo.

We found that this in vitro podocyte injury model could reproducibly mimic many of the podocyte morphological and actin cytoskeletal changes seen during NS in vivo. These changes included alterations in cell morphology and size, process retraction, and actin filament disruption. In addition, the low-dose PAN treatment induced significant hsp27 accumulation in 
podocytes, similar to our earlier findings of glomerular hsp27 accumulation in experimental NS in vivo, providing further validation of the in vitro model. Because of these similarities, we believe this model has significant potential to permit more mechanistic studies of podocyte pathobiology during PAN-induced injury in the future.

We tested several concentrations of PAN in this treatment regime and discovered two distinct responses of cultured murine podocytes at either a low (1.25 $\mu \mathrm{g} / \mathrm{ml})$ or high $(5 \mu \mathrm{g} / \mathrm{ml})$ concentration. Previously described PAN treatments of cultured podocytes (32, 33) used higher PAN concentrations $(50-100 \mu \mathrm{g} / \mathrm{ml})$ over shorter periods $(20-72 \mathrm{~h})$ with results similar to the response of vector control cells treated with 5.0 $\mu \mathrm{g} / \mathrm{ml}$ PAN for 7 days in this study. This response was characterized by cell retraction, rounding, and detachment, as well as disruption of the actin cytoskeleton. Although treatment with $1.25 \mu \mathrm{g} / \mathrm{ml}$ PAN for 7 days also resulted in discernible rearrangements of actin stress fibers, the number of live cells, the mean cell area, and the F-actin content of these cells all actually increased significantly, reflecting a fundamentally distinct biological response from that previously reported.

This reciprocal response of podocytes to low vs. higher concentrations of PAN demonstrates that podocytes can respond to a stressor with relevance to NS in at least two distinct fashions: 1) by active processes such as expansion of cell area, an increase in F-actin content, and increased cell survival or proliferation, or 2) by responses more characteristic of a toxic effect such as cell process retraction, a decrease in F-actin content, and decreased cell survival. We thus speculate that the low-concentration PAN treatment regime may be more relevant to podocyte changes that occur in typical idiopathic NS in vivo, since little or no podocyte death has been associated with this disease (34) and the effacement observed in vivo is characterized by a loss of distinctive foot process morphology and a decrease in cell perimeter (35), but not by a radical reduction in the podocyte area in contact with the GBM. In contrast, the higher concentration PAN treatment regime may be more relevant to podocyte changes that occur in more resistant forms of NS, such as focal segmental glomerulosclerosis, where more severe podocyte injury and retraction may result in 1) detachment of foot processes from the GBM and subsequent formation of synechiae, 2) decreased podocyte survival that results in podocyte loss in the urine (36), and ultimately 3) development of chronic renal insufficiency.

We also found that alterations in hsp27 levels were able to regulate a variety of podocyte characteristics in the absence of any treatment. Hsp27 has been reported by numerous investigators to have both positive and negative roles in the regulation of actin filament dynamics. It has been identified as an barbed-end filament capping protein in vitro (37) and has been reported to inhibit recovery of actin filaments and focal adhesions induced by disruption via heat shock and to delay reattachment and limit recovery of actin filaments
(23). In contrast to these negative effects, hsp27 has also been reported to confer protection against actin filament disruption caused by oxidants (38), to provide partial protection against cell death caused by hydrogen peroxide treatment (38), and to suppress actin filament disruption induced by cytochalasin $\mathrm{D}$ as well as accelerating the reassembly of actin stress fibers (15, 39). Our results are entirely consistent with a protective role for hsp27 in the regulation of actin filaments. We found that modulation of hsp27 expression alone (in the absence of PAN treatment) in podocytes consistently resulted in morphological and actin cytoskeletal alterations.

The effects of altered hsp27 phosphorylation on podocyte morphology and actin cytoskeletal structure, however, were less clear. Although the hsp27 sense cells contained a larger amount of phosphorylated hsp27 than either the vector or antisense cells, they also had a lower percentage of hsp27 phosphorylation than either of the other cells. The relative biological importance of the absolute amount vs. relative phosphorylation of hsp27 is not yet understood, but hsp27 phosphorylation itself is known to have important effects on hsp27 function. Phosphorylation has been shown to abolish the ability of hsp27 to inhibit actin polymerization in vitro (37) and to regulate the organization of hsp27 into multimers (40). Chinese hamster fibroblasts overexpressing a nonphosphorylatable mutant hsp27 protein have been reported to have a reduced F-actin content and a delay in growth factor-induced actin polymerization (15), and actin filaments in these cells were more sensitive to heat shock-induced disruption (24). Although these studies made no attempt to quantify the absolute or relative amounts of phosphorylated hsp27 present in transfectants, they do suggest that the amount of phosphorylated (or unphosphorylated) hsp27 present in cells may be a determining factor in regulating actin filament structure by hsp27. Our results can thus be interpreted in one of two ways: that the quantity 1) of total hsp27 or 2) of either the unor monophosphorylated hsp27 isoform is primarily responsible for the effects of hsp27 on podocyte morphology and the actin cytoskeleton. However, since both sense and antisense transfection resulted in less relative phosphorylation of hsp27 than controls yet displayed divergent and largely opposite effects on podocytes, we conclude that differences in the relative phosphorylation of hsp27 were not responsible for the changes observed. Further studies to determine the effects of stable expression of hsp27 mutant proteins that are nonphosphorylatable or pseudo-phosphorylated are under way in our laboratory to clarify the role of hsp27 phosphorylation on podocyte structure.

Our findings also demonstrated the ability of hsp27 to regulate a variety of cellular responses of podocytes to PAN-induced injury. Podocyte hsp27 levels correlated directly with resistance to PAN-induced cell death. This finding is entirely consistent with hsp27's known chaperonin function $(41,42)$. Alternatively, although we did not determine whether cell death was due to 
apoptosis vs. necrosis, this protection may have resulted from hsp27's reported role in protection against apoptosis (43). Hsp27 was also able to regulate the podocyte morphological and actin cytoskeletal responses to PAN. Compared with the morphological changes and quantitative and qualitative disruption of actin filaments seen in vector control cells, cells containing greater amounts of hsp27 were markedly protected whereas cells expressing lesser amounts of hsp27 were markedly more sensitive to PAN-induced injury. Although hsp27 has been reported to function as either a chaperonin or regulator of the actin cytoskeleton, the pronounced actin cytoskeletal effects seen in the current studies suggest that hsp27's major role in podocytes is probably in the regulation of the actin cytoskeleton.

In summary, we analyzed murine podocytes stably transfected with hsp27 sense, antisense, and vector control constructs using a newly developed in vitro PAN model system designed to mimic the podocyte structural changes seen in NS. We found that hsp27 is able to regulate many key structural features of podocytes. More importantly, we also found that hsp27 is able to regulate the morphological and actin cytoskeletal response of podocytes to injury induced by PAN, a toxic compound used in a well-established in vivo model of NS. In conjunction with our earlier findings of increased glomerular hsp27 expression and phosphorylation during PAN-induced NS, these findings suggest that hsp27 may have an important role in regulating the podocyte structural changes observed during the development of and/or recovery from nephrotic syndrome.

This work was supported in part by National Institutes of Health grant K08 DK02455-01 and a Research Grant from the National Kidney Foundation of Michigan to W.E.S.

\section{REFERENCES}

1. Farquhar, M. G., Vernier, R. L., and Good, R. A. (1957) An electron microscopic study of the glomerulus in nephrosis, glomerulonephritis and lupus erythematosus. J. Exp. Med. 106, 649-660

2. Vernier, R. L., Papermaster, B. W., and Good, R. A. (1958) Aminonucleoside nephrosis. I. Electron microscopic study of the renal lesion in rats. J. Exp. Med. 109, 115-126

3. Ryan, G. P., and Karnovsky, M. J. (1975) An ultrastructural study of the mechanisms of proteinuria in aminonucleoside nephrosis. Kidney Int. 8, 219-232

4. Caulfield, J. P., Reid, J. J., and Farquhar, M. G. (1976) Alterations of the glomerular epithelium in acute aminonucleoside nephrosis. Evidence for formation of occluding junctions and epithelial cell detachment. Lab. Invest. 34, 43-59

5. Smoyer, W. E., and Mundel, P. (1998) Regulation of podocyte structure during the development of nephrotic syndrome. $J$. Mol. Med. 76, 172-183

6. Glassock, R. J. (1988) Pathogenesis of the nephrotic syndrome. In The Nephrotic Syndrome (Cameron, J. S., and Glassock, R. J., eds) pp. 163-192, Marcel Dekker, New York

7. Ito, K., Ger, Y. C., and Kawamura, S. (1986) Actin filament alterations in glomerular epithelial cells of adriamycin-induced nephrotic rats. Acta Pathol. Jpn. 36, 253-260

8. Lachapelle, M., and Bendayan, M. (1991) Contractile proteins in podocytes: Immunochemical localization of actin and alpha- actinin in normal and nephrotic rat kidneys. Virchows Arch. B Cell. Pathol. 60, 105-111

9. Whiteside, C. I., Cameron, R., Munk, S., and Levy, J. (1993) Podocytic cytoskeletal disaggregation and basement-membrane detachment in puromycin aminonucleoside nephrosis. Am. J. Pathol. 142, 1641-1653

10. Andrews, P. M., and Bates, S. B. (1984) Filamentous actin bundles in the kidney. Anat. Rec. 210, 1-9

11. Vasmant, D., Maurice, M., and Feldmann, G. (1984) Cytoskeletal ultrastructure of podocytes and glomerular endothelial cells in man and in the rat. Anat. Rec. 210, 17-24

12. Smoyer, W. E., Gupta, A., Mundel, P., Ballew, J. D., and Welsh, M. J. (1996) Altered expression of glomerular heat shock protein 27 in experimental nephrotic syndrome. J. Clin. Invest. 97, 2697-2704

13. Ciocca, D. R., Oesterreich, S., Chamness, G. C., McGuire, W. L., and Fuqua, S. A. W. (1993) Biological and clinical implications of heat shock protein 27,000 (Hsp27): a review. J. Natl. Cancer Inst. 85, 1558-1570

14. Jakob, U., Gaestel, M., Engel, K., and Buchner, J. (1993) Small heat shock proteins are molecular chaperones. J. Biol. Chem. 268, 1517-1520

15. Lavoie, J., Hickey, E., Weber, L. A., and Landry, J. (1993) Modulation of actin microfilament dynamics and fluid phase pinocytosis by phosphorylation of heat shock protein 27. J. Biol. Chem. 268, 24210-24214

16. Mehlen, P., Preville, X., Chareyron, P., Briolay, J., Klemenz, R., and Arrigo, A. P. (1995) Constitutive expression of human hsp27, Drosophila hsp27 or human $\alpha$ B-crystallin confers resistance to TNF- and oxidative stress-induced cytotoxicity in stably transfected murine L929 fibroblasts. J. Immunol. 154, 363-374

17. Huot, J., Roy, G., Lambert, H., Chretien, P., and Landry, J. (1991) Increased survival after treatments with anticancer agents of Chinese hamster cells expressing the human $\mathrm{Mr}$ 27,000 heat shock protein. Cancer Res. 51, 5245-5252

18. Landry, J., Chretien, P., Lambert, H., Hickey, E., and Weber, L. A. (1989) Heat shock resistance conferred by expression of the human HSP27 gene in rodent cells. J. Cell Biol. 109, 7-15

19. Arrigo, A. P., and Landry, J. (1994) Expression and function of the low-molecular-weight heat shock proteins. In The Biology of Heat Shock Proteins and Molecular Chaperones (Morimoto, R. I., Tissieres, A., and Georgopoulos, C., eds) pp. 335-373, Cold Spring Harbor Laboratory Press, Plainview, New York

20. Mehlen, P., Schulze-Osthoff, K., and Arrigo, A. P. (1996) Small stress proteins as novel regulators of apoptosis. Heat shock protein 27 blocks Fas/APO-1- and staurosporine-induced cell death. J. Biol. Chem. 271, 16510-16514

21. Miron, T., Wilchek, M., and Geiger, B. (1988) Characterization of an inhibitor of actin polymerization in vinculin-rich fraction of turkey gizzard smooth muscle. Eur. J. Biochem. 178, 543-553

22. Miron, T., Wilchek, M., and Geiger, B. (1991) A 25 kD inhibitor of actin polymerization is a low molecular mass heat shock protein. J. Cell Biol. 114, 255-261

23. Schneider, G. B., Hamano, H., and Cooper, L. F. (1998) In vivo evaluation of hsp27 as an inhibitor of actin polymerization: hsp27 limits actin stress fiber and focal adhesion formation after heat shock. J. Cell. Physiol. 177, 575-584

24. Lavoie, J. N., Lambert, H., Hickey, E., Weber, L. A., and Landry, J. (1995) Modulation of cellular thermoresistance and actin filament stability accompanies phosphorylation-induced changes in the oligomeric structure of heat shock protein 27. Mol. Cell. Biol. 15, 505-516

25. Mundel, P., Reiser, J., Zuniga, A., Borja, M., Pavenstadt, H., Davidson, G., Kriz, W., and Zeller, R. (1997) Rearrangements of the cytoskeleton and cell contacts induce process formation during differentiation of conditionally immortalized mouse podocyte cell lines. Exp. Cell Res. 236, 248-258

26. Hickey, E., Brandon, S. E., Potter, R., Stein, G., Stein, J., and Weber, L. A. (1986) Sequence and organization of genes encoding the human $27 \mathrm{kDa}$ heat shock protein. Nucleic Acids Res. 14, 4127-4145

27. Wu, W., and Welsh, M. J. (1996) Expression of the 25-kDa heat-shock protein (HSP27) correlates with resistance to the toxicity of cadmium chloride, mercuric chloride, cis-platinum(II)-diamine dichloride, or sodium arsenite in mouse embryonic stem cells transfected with sense or antisense HSP27 cDNA. Toxicol. Appl. Pharmacol. 141, 330-339 
28. Shelden, E. (1999) Major role for active extension in the formation of processes by ras-transformed fibroblasts. Cell Motil. Cytoskel. 42, 12-26

29. Singhal, P. C., Franki, F., Gibbons, N., and Hays, R. M. (1992) Effects of angiotensin II and arginine vasopressin on F-actin content of cultured mesangial cells. J. Am. Soc. Nephrol. 3, 80-87

30. Smith, P. K., Krohn, R. I., Hermanson, G. T., Mallia, A. K. Gartner, F. H., Provenzano, M. D., Fujimoto, E. K., Goeke, N. M., Olson, B. J., and Klenk, D. C. (1985) Measurement of protein using bicinchoninic acid. Anal. Biochem. 150, 76-85

31. Stokoe, D., Engel, K., Campbell, D. G., Cohen, P., and Gaestel, M. (1992) Identification of MAPKAP kinase 2 as a major enzyme responsible for the phosphorylation of the small mammalian heat shock proteins. FEBS Lett. 313, 317-313

32. Fishman, J. A., and Karnovsky, M. J. (1985) Effects of the aminonucleoside of puromycin on glomerular epithelial cells in vitro. Am. J. Pathol. 118, 398-407

33. Reiser, J., Pixley, F. J., Hug, A., Kriz, W., Smoyer, W. E., Stanley, E. R., and Mundel, P. (2000) Regulation of mouse podocyte process dynamics by protein tyrosine kinases. Kidney Int. $\mathbf{5 7}$ 2035-2042

34. Hara, M., Yanagihara, T., Takada, T., Itoh, M., Matsuno, M., Yamamoto, T., and Kihara, I. (1998) Urinary excretion of podocytes reflects disease activity in children with glomerulonephritis. Am. J. Nephrol. 18, 35-41

35. Inokuchi, S., Shirato, I., Kobayashi, N., Koide, H., Tomino, Y., and Sakai, T. (1996) Re-evaluation of foot process effacement in acute puromycin aminonucleoside nephrosis. Kidney Int. 50, $1278-1287$

36. Nakamura, T., Ushiyama, C., Suzuki, S., Hara, M., Shimada, N., Ebihara, I., and Koide, H. (2000) The urinary as a marker for the differential diagnosis of idiopathic focal glomerulosclerosis and minimal-change nephrotic syndrome. Am. J. Nephrol. 20, 175-179
37. Benndorf, R., Hayess, K., Ryazantsev, S., Wieske, M., Behlke, J., and Lutsch, G. (1994) Phosphorylation and supramolecular organization of murine small heat shock protein HSP25 abolish its actin polymerization-inhibiting activity. J. Biol. Chem. 269, 20780-20784

38. Huot, J., Houle, F., Spitz, D. R., and Landry, J. (1996) HSP27 phosphorylation-mediated resistance against actin fragmentation and cell death induced by oxidative stress. Cancer Res. 56 , 273-279

39. Lavoie, J. N., Gingras-Breton, G., Tanguay, R. M., and Landry, J. (1993) Induction of Chinese hamster hsp27 gene expression in mouse cells confers resistance to heat shock: hsp27 stabilization of the microfilament organization. J. Biol. Chem. 268, 3420-3429

40. Lambert, H., Charette, S. J., Bernier, A. F., Guimond, A., and Landry, J. (1999) HSP27 multimerization mediated by phosphorylation-sensitive intermolecular interactions at the amino terminus. J. Biol. Chem. 274, 9378-9385

41. Knauf, U., Jakob, U., Engel, K., Buchner, J., and Gaestel, M. (1994) Stress- and mitogen-induced phosphorylation of the small heat shock protein Hsp25 by MAPKAP kinase 2 is not essential for chaperone properties and cellular thermoresistance. EMBO J. 13, 54-60

42. Ehrnsperger, M., Graber, S., Gaestel, M., and Buchner, J. (1997) Binding of nonnative protein to HSP25 during heat shock creates a reservoir of folding intermediates for reaction. $E M B O$ J. 16, 221-229

43. Garrido, C., Gurbuxani, S., Ravagnan, L., and Kroemer, G. (2001) Heat shock proteins: endogenous modulators of apoptotic cell death. Biochem. Biophys. Res. Commun. 286, 433-442

Received for publication September 6, 2001. Accepted for publication November 5, 2001. 